\title{
Level and quality of protein in rations for lactating ewes
}

\author{
C Jaime, A Purroy * \\ Unidad de Producción Animal, Servicio de Investigación Agraria (DGA), \\ Apartado 727, 50080 Zaragoza, Spain
}

(Received 3 November 1993; accepted 9 August 1994)

\begin{abstract}
Summary - The effect of 2 levels of crude protein in the ration (110 and $90 \%$ of theoretical requirements) and of 3 main protein sources in the concentrate (faba beans, soybean cake and fish meal) on changes in live weight and body condition score, milk production, plasma concentration of non-esterified fatty acids and urea, and lamb growth was studied in 36 lactating Rasa Aragonesa ewes rearing 2 lambs submitted to an energy restriction level of $30 \%$ of their theoretical requirements. The average decreases in live weight and body condition score of the ewes were not significantly affected by the two effects studied. The ewes that were given the higher protein level produced more milk, fat, protein, total dry matter and blood urea concentration than those that received the lower level $(P<0.05)$. A trend towards significance was observed in the maximum concentrations of non-esterified fatty acids according to the protein source $(P=0.07)$. No significant differences were found in the results of lamb growth.
\end{abstract}

\section{protein / body condition / milk production / sheep / lambs}

Résumé - Niveau et qualité des protéines dans la ration des brebis en lactation. On a étudié chez 36 brebis Rasa Aragonesa allaitant 2 agneaux, et ne recevant que $70 \%$ de leurs besoins énergétiques théoriques, l'effet de 2 niveaux de matières azotées totales dans la ration (110 et $90 \%$ des besoins théoriques) et de 3 sources de protéine dans l'aliment concentré (féveroles, tourteau de soja et farine de poisson), sur les changements de poids vif et de note d'état corporel, sur la production de lait, la concentration plasmatique d'acides gras non estérifiés et d'urée, ainsi que sur la croissance des agneaux. Les 2 effets étudiés n'ont pas modifié les pertes de poids vif et de note d'état corporel des brebis. Les mères avec le niveau le plus élevé de matières azotées dans la ration ont eu des productions de lait, de matière grasse, de matière azotée, de matière sèche totale et une concentration d'urée plasmatique plus élevées que celles avec un niveau plus bas $(P<0,05)$. Une tendance vers la signification a été observée dans la concentration maximum des acides gras non estérifiés selon la source de protéine utilisée $(\mathrm{P}=0,07)$. II n'a pas eu de différences significatives dans la croissance des agneaux.

\section{protéine / état corporel / production laitière / brebis / agneaux}

* Correspondence and reprints: Departamento de Producción Agraria, Universidad Pública de Navarra, Campus de Arrosadía s/n, 31006 Pamplona, Spain. 


\section{INTRODUCTION}

The highest nutritional requirements of ewes occur during the first 4-6 weeks of lactation, when the energy and protein requirements for milk production may be up to 3 and 4 times higher than for maintenance (Robinson, 1988). During this period, the ewes cannot consume all the food that is necessary to meet their nutritional requirements, and therefore must mobilize their body reserves in order to compensate for the dietary deficiency (MLC, 1981).

For a specific level of ingested metabolizable energy, the increase in the protein content of the ration leads to a rise in milk production when the ewe has not reached its maximum milk production potential. This response seems to be enhanced in ewes with high restrictions in energy intake (Robinson et al, 1974; 1979), although positive responses have also been found with energy intake close to the theoretical requirements (González et al, 1984). This phenomenon can be due either to a greater mobilization of body reserves (Robinson et al, 1974) or to an increase in the efficiency of utilization of these reserves for milk production (Cowan et al, 1981).

On the other hand, as the degradability of dietary protein in the rumen decreases, the amount of milk produced by the ewe increases (Robinson et al, 1979; González et al, 1982). Only a small part of the proteins exported in the milk comes from body reserves (about $20 \%$; Cowan et al, 1981); the rest comes from the microbial proteins and from the dietary protein that has not been degraded in the rumen. Nevertheless, more recent results do not show a strong relationship between a lower degradability of protein and milk production (Penning et al, 1988; Ngongoni et al, 1989; Hadjipanayiotou, 1992).

The present study investigates the effect of the protein level in the ration and of the quality of the protein source in the concentrate on the yield and composition of the milk of lactating ewes. The energy requirements of these ewes are restricted to stimulate the mobilization of body reserves. Data are also presented for live weight, body condition score and plasma concentration of non-esterified fatty acids as indicators of body reserve mobilization.

\section{MATERIAL AND METHODS}

Thirty-six lactating Rasa Aragonesa ewes, each suckling 2 lambs, were used in this trial. They were kept in individual pens under a regime of energy intake restriction consisting of $30 \%$ of the theoretical requirements of a standard ewe of $40 \mathrm{~kg}$ live weight producing $1.50 \mathrm{~kg} \mathrm{milk} /$ day $(2.98 \mathrm{Mcal} / \mathrm{d})$ (INRA, 1988). The ration was made up of barley straw (20\%, $250 \mathrm{~g} \mathrm{DM} / \mathrm{d})$, alfalfa hay $(40 \%, 535 \mathrm{~g}$ $\mathrm{DM} / \mathrm{d})$ and concentrate $(40 \%, 550 \mathrm{~g} \mathrm{DM} / \mathrm{d})$.

During the 1 st week of lactation, the ewes were given a ration with $215 \mathrm{~g} / \mathrm{d}$ crude protein (CP) and soybean cake as the main protein source of the concentrate to use the initial milk production as a covariate to correct the total milk production. On the 8th day after lambing, they were distributed into 6 homogeneous treatments in terms of live weight $(\mathrm{LW}=40.4 \pm 5.28)$ and body condition score $(B C s=2.4 \pm 0.32)$ at lambing (Russel et al, 1969), following a $2 \times 3$ factorial model, with 2 levels of $C P$ in the ration and 3 main protein sources of different degradability in the concentrate. The first protein level $\left(\mathrm{PL}_{1}=\right.$ $215 \mathrm{~g} \mathrm{CP} / \mathrm{d}, 16.1 \% \mathrm{CP}$ ) was $10 \%$ higher than the theoretical requirements of the standard ewe described earlier, which would lose 0.5 points of $\mathrm{BCs}$ in the first 6 weeks of lactation, while the second level $\left(\mathrm{PL}_{2}=175 \mathrm{~g} \mathrm{CP} / \mathrm{d}, 13.1 \% \mathrm{CP}\right)$ restricted those requirements by $10 \%$ (MLC, 1981). The 3 main protein sources studied in the concentrate were: faba beans (FB), soybean cake (SBC) and fish meal (FM). The duration of the experimental period was $37 \mathrm{~d}$. Tables I and II show the composition of the feeds used.

The lambs were given commercial concentrate from the end of the experimental period (day 44 after lambing) until weaning (day 62).

The ewes and the lambs were weighed twice a week, and the body condition score of the ewes was determined once a week. The changes in live weight and body condition score were cal- 
Table I. Composition of the concentrates (percentage of dry matter, DM).

\begin{tabular}{|c|c|c|c|c|c|}
\hline & $F B_{1}$ & $F B_{2}$ & $S B C_{1}$ & $S B C_{2}$ & $F M_{1}$ \\
\hline $\begin{array}{l}\text { Barley } \\
\text { Faba beans }\end{array}$ & $\begin{array}{l}34.0 \\
63.0\end{array}$ & $\begin{array}{l}75.5 \\
215\end{array}$ & 71.0 & 88.0 & 78.5 \\
\hline Soybean cake & & & 26.0 & 9.0 & \\
\hline Fish meal & & & & & 18.5 \\
\hline $\mathrm{HPO}_{4} \mathrm{Ca}$ & 2.0 & 2.0 & 2.0 & 2.0 & 2.0 \\
\hline $\mathrm{NaCl}^{4}$ & 0.65 & 0.65 & 0.65 & 0.65 & 0.65 \\
\hline Mineral-Vitaminic corrector & 0.35 & 0.35 & 0.35 & 0.35 & 0.35 \\
\hline
\end{tabular}

$1=$ higher and ${ }_{2}=$ lower level of protein; FB = faba beans; $S B C=$ soybean cake; FM = tish meal.

Table II. Percentage of dry matter (DM), organic matter (OM), crude protein (CP) and neutraldetergent fiber (NDF) in the concentrates, in alfalfa hay (alf hay) and in barley straw (barl str).

$\begin{array}{lcccc} & D M & O M & C P & \text { NDF } \\ & & & & \\ \mathrm{FB}_{1} & 90.11 & 94.64 & 20.76 & 29.55 \\ \mathrm{SBC}_{1} & 89.77 & 90.61 & 18.94 & 26.35 \\ \mathrm{FM}_{1} & 90.47 & 90.00 & 20.90 & 26.60 \\ \mathrm{FB}_{2} & 89.90 & 93.29 & 14.43 & 26.85 \\ \mathrm{SBC}_{2} & 89.64 & 95.01 & 14.81 & 29.30 \\ \mathrm{FM}_{2} & 89.93 & 93.93 & 13.20 & 26.15 \\ \text { alf hay } & 88.67 & 88.76 & 16.55 & 44.85 \\ \text { barl str } & 85.28 & 91.48 & 3.86 & 75.27\end{array}$

${ }_{1}=$ higher and ${ }_{2}=$ lower level of protein; $F B=$ faba beans; $\mathrm{SBC}=$ soybean cake; FM : fish meal.

culated based on the individual linear regressions of each variable with regard to time.

Milk production was estimated once a week by manual milking after injected oxytocin (Doney et al, 1979); the fat, protein and total solids of the milk were also determined. Total fat, protein, dry matter and milk production were estimated by the Fleischmann method.

Blood samples were taken from the jugular vein on a weekly basis before feeding in the morning for the determination of non-esterified fatty acids (NEFA) (Wako NEFAC Chemicals GmbH, Germany) and plasma urea (UREA COLOR Boehringer Biochemia Robin, Germany).
Data were subjected to analysis of variance, covariance, regression and correlation by means of the SAS statistical package (1987).

\section{RESULTS}

Table III shows the intake of DM, CP and metabolizable energy (ME) by the ewes on the 6 treatments.

The effect of the level and quality of protein were not significantly different in live weight and body condition score changes, and the average decreases in LW and BCs were $5.3 \pm 1.78 \mathrm{~kg}$ and $0.4 \pm 0.17$ points, respectively. Figures 1 and 2 represent the evolution of $L W$ and $B C s$, respectively, as a function of time.

The milk production data are presented in table IV. The animals that were given the higher protein level $\left(\mathrm{PL}_{1}\right)$ produced more milk than those on the lower level $\left(\mathrm{PL}_{2}\right)(1.08$ vs $0.95 \mathrm{~kg} / \mathrm{d} ; P<0.05)$. When the total milk production was corrected for covariance by using the initial milk production as the covariate, the protein level effect remained, the new adjusted values being $1.06\left(\mathrm{PL}_{1}\right)$ and $0.97 \mathrm{~kg} / \mathrm{d}\left(\mathrm{PL}_{2}\right)(\mathrm{RSD}=0.119)$.

The ewes on $\mathrm{PL}_{1}$ produced greater amounts of fat, protein and total dry matter than those on $\mathrm{PL}_{2}(P<0.05)$, but when the data were corrected for covariance, the effect 
Table III. Daily intake of dry matter (DM), metabolizable energy (ME) and crude protein (CP).

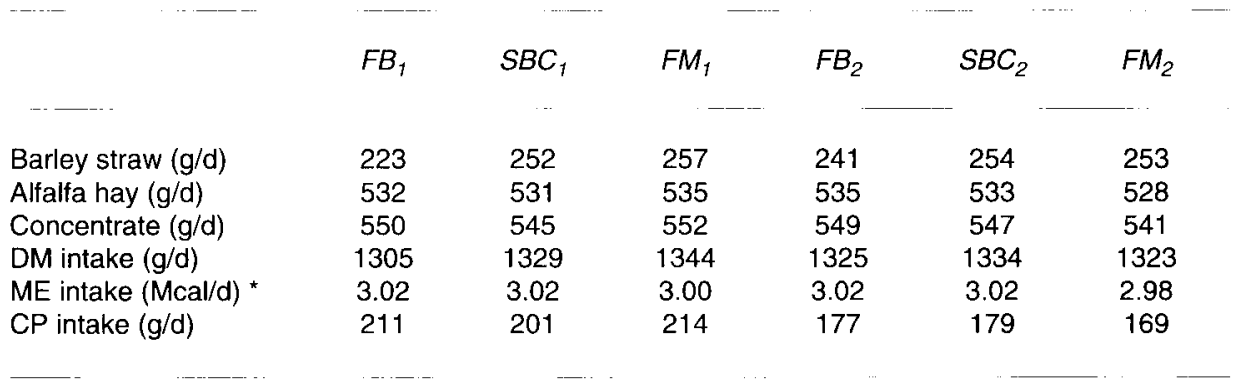

* From INRA, 1988. ${ }_{1}=$ higher and $_{2}=$ lower level of protein; $F B=$ faba beans; $S B C=$ soybean cake; $F M=$ fish meal.

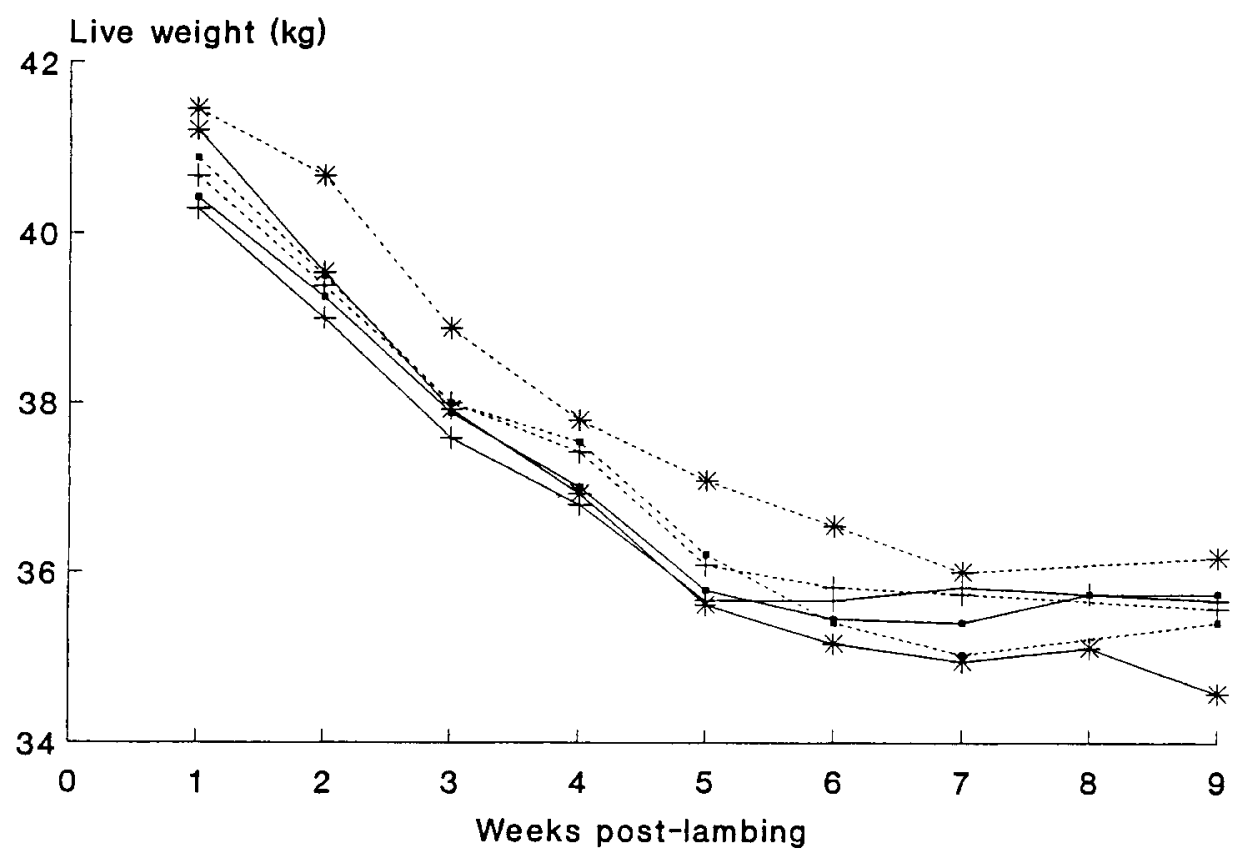

Fig 1. The evolution of the live weight according to the protein level ( - higher, -- lower) and the protein source ( $\mathbf{\square}$ faba beans, + soybean cake, ${ }^{\star}$ fish meal).

of protein level on fat was removed $(P=$ 0.217 ; RSD $=16.035$, , partially on total dry matter $(P=0.096$; RSD $=27.438)$ although it remained on protein (RSD $=6.063$ ).

No significant differences were found in the final live weights, mean daily gains, milk and total dry matter conversion index of the lamb litters, the mean values being $14.7 \pm$ $1.97 \mathrm{~kg} ; 197 \pm 34.4 \mathrm{~g} / \mathrm{d} ; 5.21 \pm 0.742$ and $0.99 \pm 0.149 \mathrm{~kg} / \mathrm{kg}$, respectively. However, higher concentrate intakes were observed during the 18 days preceding weaning in the litters corresponding to $\mathrm{PL}_{2}$ (6.3 vs 5.0 $\mathrm{kg} /$ litter; $P=0.07$ ). Figure 3 illustrates the 


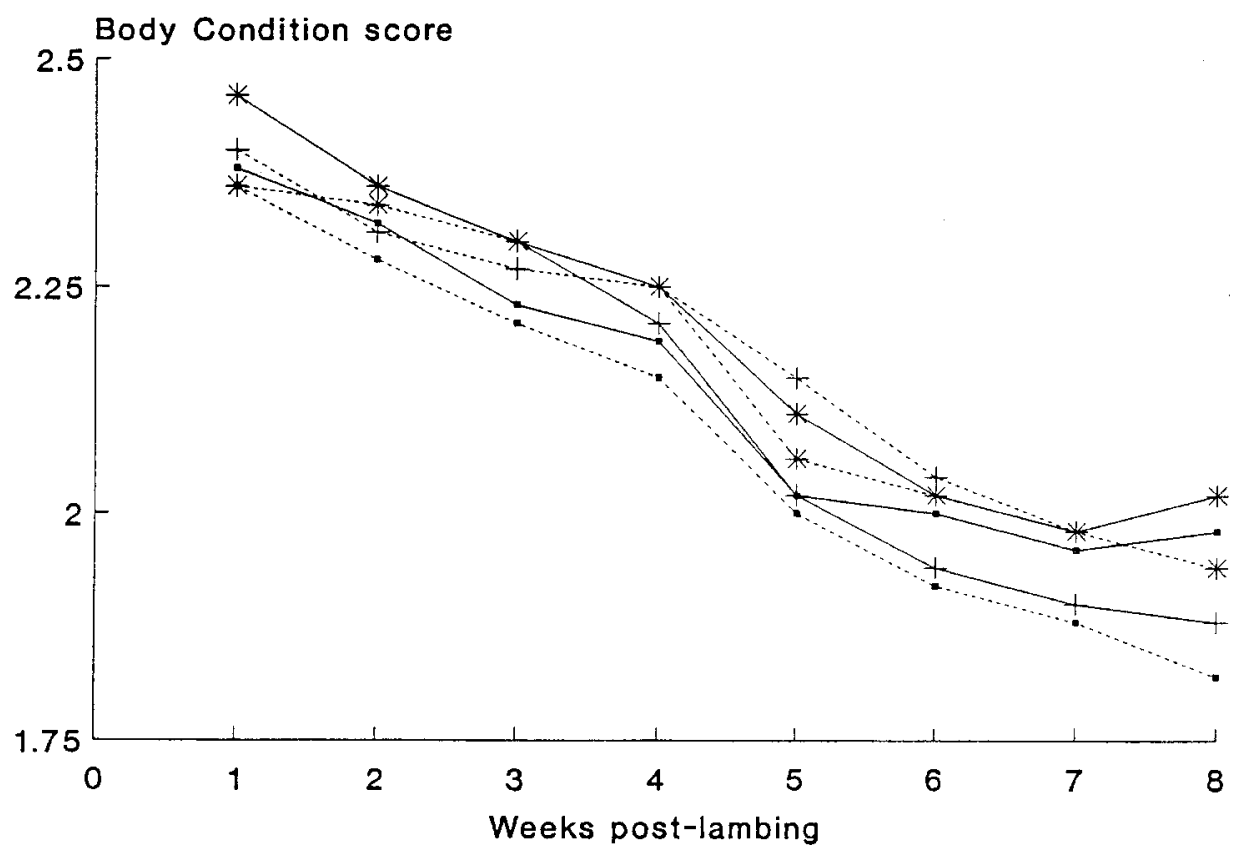

Fig 2. The evolution of the body condition score according to the protein level ( - higher, --- lower) and the protein source ( $\square$ faba beans, + soybean cake, ${ }^{*}$ fish meal).

live weight evolution of the litters under each treatment, and shows that the slope of the curve of the litters from the ewes under the higher protein level with fish meal in the concentrate was higher than all the others.
A trend towards significance was observed in the maximum concentration of NEFA according to the protein source $(P=0.07$; $\mathrm{RSD}=0.309$ ), which became significant once it was corrected for covariance by using the

Table IV. Initial(i) and daily (d) milk production (MP), fat(F), protein (P) and total dry matter (TD) in percentage $(\%)$ and daily, according to the protein level $(\mathrm{PL})$ in the ration and the protein source (PS) of the concentrate.

$$
F B_{1} \quad S B C_{1} \quad F M_{1} \quad F B_{2} \quad S B C_{2} \quad F M_{2} \quad R S D \quad P L \quad P S \quad P L \times P S
$$

$\begin{array}{lcccccccccc}\mathrm{MPi}(\mathrm{kg} / \mathrm{d}) & 1.20 & 1.25 & 1.32 & 1.20 & 1.10 & 1.10 & 0.286 & \mathrm{NS} & \mathrm{NS} & \mathrm{NS} \\ \mathrm{MPd}(\mathrm{kg} / \mathrm{d}) & 0.98 & 1.07 & 1.19 & 0.97 & 0.98 & 0.90 & 0.160 & \star & \text { NS } & \text { NS } \\ \mathrm{F}(\%) & 8.11 & 8.22 & 8.09 & 7.91 & 7.37 & 8.44 & 1.431 & \mathrm{NS} & \mathrm{NS} & \mathrm{NS} \\ \mathrm{Fd}(\mathrm{g} / \mathrm{d}) & 79 & 88 & 97 & 75 & 72 & 76 & 18.72 & * & \mathrm{NS} & \mathrm{NS} \\ \mathrm{P}(\%) & 5.06 & 5.06 & 5.20 & 5.10 & 5.01 & 5.27 & 0.357 & \mathrm{NS} & \mathrm{NS} & \mathrm{NS} \\ \mathrm{Pd}(\mathrm{g} / \mathrm{d}) & 49 & 54 & 62 & 49 & 49 & 48 & 7.76 & { }^{*} & \mathrm{NS} & \mathrm{NS} \\ \mathrm{TD}(\%) & 19.0 & 19.1 & 19.1 & 19.0 & 18.3 & 19.5 & 1.678 & \mathrm{NS} & \mathrm{NS} & \mathrm{NS} \\ \mathrm{TDd}(\mathrm{g} / \mathrm{d}) & 185 & 204 & 228 & 182 & 179 & 176 & 32.65 & * & \mathrm{NS} & \mathrm{NS}\end{array}$


initial concentration as the covariate $(P<$ $0.05 ; \mathrm{RSD}=0.236$ ). The new adjusted values were $1.3,1.5$ and $1.6 \mathrm{meq} / \mathrm{l}$, respectively, for the ewes receiving faba beans, soybean cake and fish meal. Figure 4 illustrates the temporal pattern for the concentration of NEFA in blood. Finally, the ewes on the higher protein level presented a higher blood urea concentration than those on the lower level (51.1 vs $47.1 \mathrm{mg} / \mathrm{dl} ; P<0.05$ ).

\section{DISCUSSION}

The losses of live weight and body condition score were the result of the strong energy restriction to which the ewes were submitted, with a significant relationship between these losses $(r=0.53 ; P<0.001)$. When the LW and the BCs losses were investigated in relation to the initial LW and $\mathrm{BCs}$ respectively, it was observed that the ewes with the highest live weight and score at the beginning of the trial were those with the highest live weight $(r=0.58 ; P<0.001)$ and score $(r=0.66 ; P<0.001)$ losses. These results are in agreement with those found by Gibb and Treacher (1980), where the ewes with the best body condition at lambing were those with the greatest mobilization of body reserves. Likewise, Cowan et al (1982) found that the amount of lipids mobilized at the beginning of lactation was greater in the ewes with a higher initial fat content.

The higher milk production obtained at high level of $\mathrm{CP}(P<0.05)$ seems to be the direct consequence of a higher daily protein intake, since according to Robinson et al (1974), when the intake of digestible organic matter remains constant, milk production increases as the crude protein/metabolizable energy (CP/ME) ratio increases. This response is more intense when the ewes are submitted to energy restrictions or when

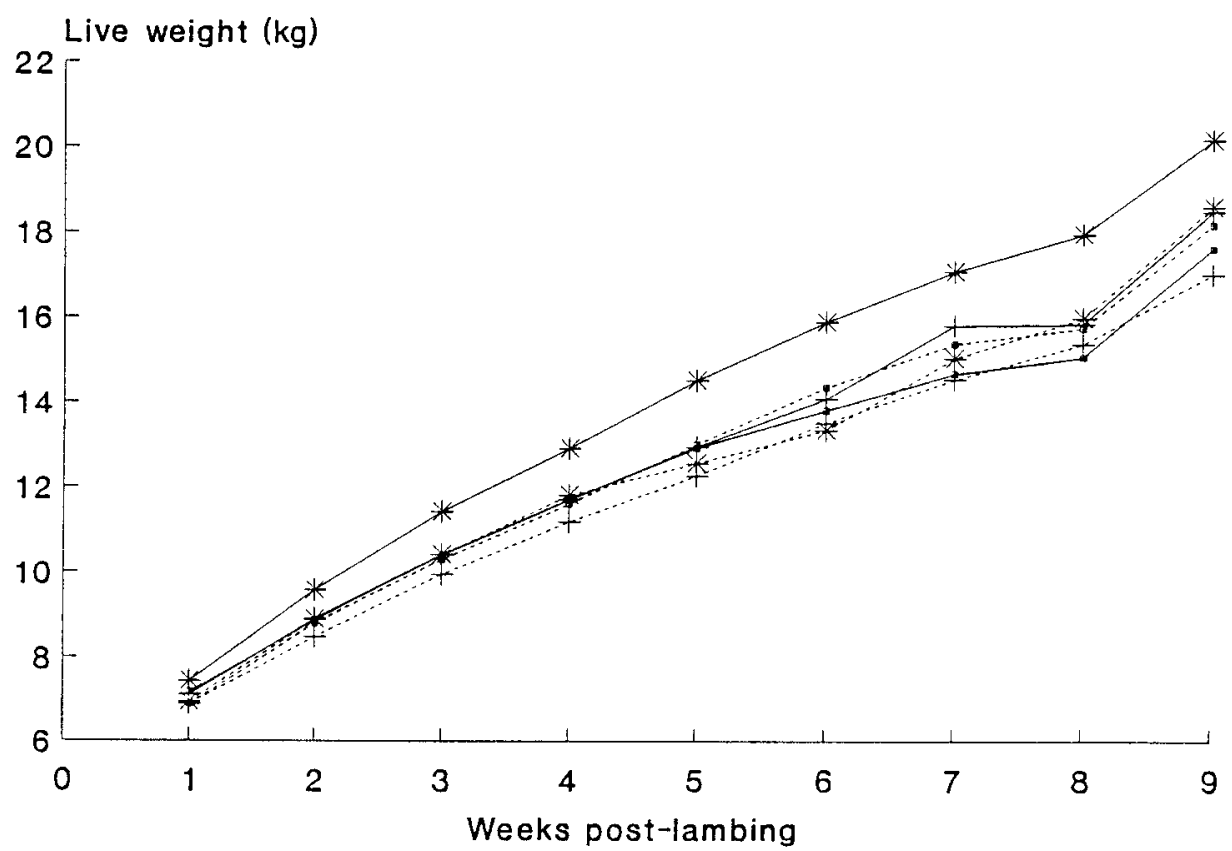

Fig 3. The evolution of the live weight of the litter according to the protein level (- higher, --- lower) and the protein source ( $\mathbf{\square}$ faba beans, + soybean cake, ${ }^{*}$ fish meal). 


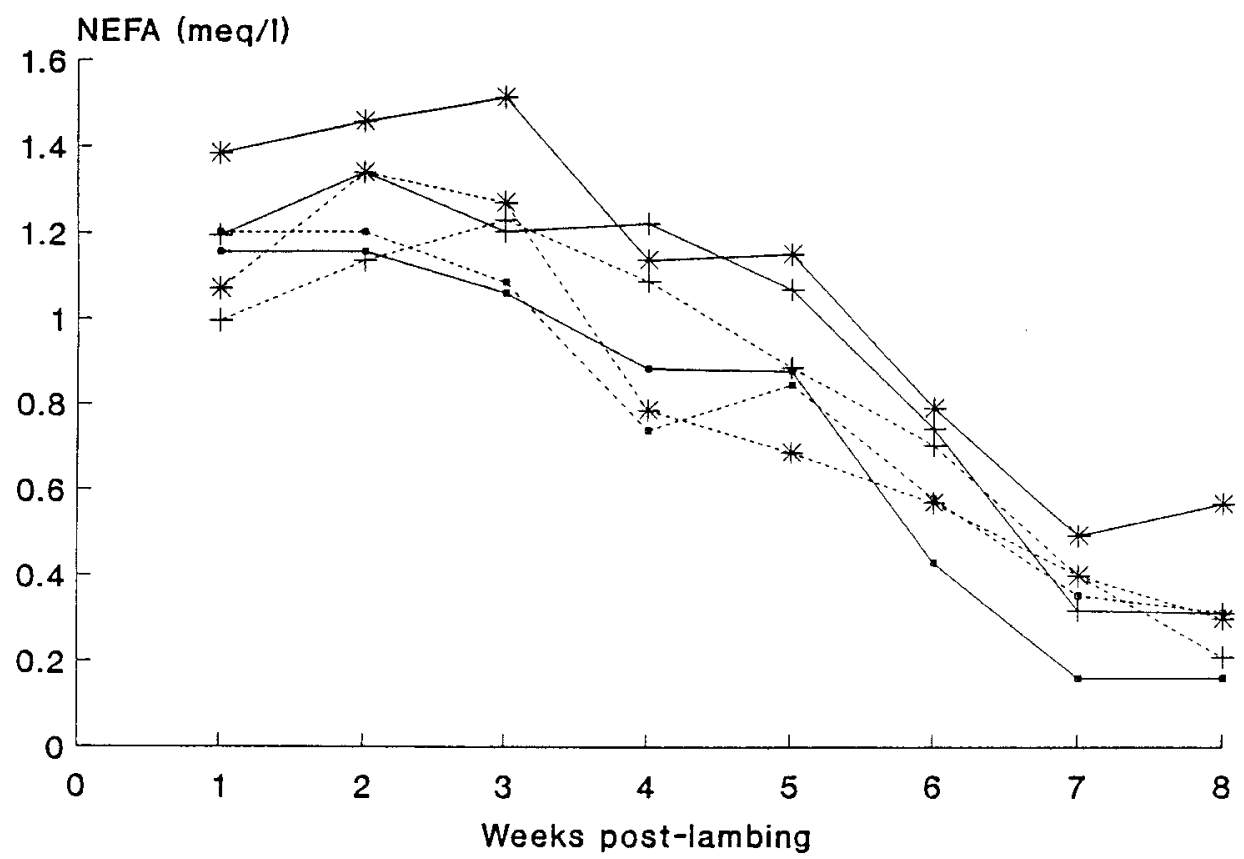

Fig 4. The evolution of the concentration of non-esterified fatty acids (NEFA) according to the protein level (- higher, --- lower) and the protein source (- faba beans, + soybean cake, " fish meal).

the CP/ME ratio does not exceed $70 \mathrm{~g} / \mathrm{Mcal}$. In this trial, the ratio was 67.5 and 56.8 $\mathrm{g} / \mathrm{Mcal}$, for levels $\mathrm{PL}_{1}$ and $\mathrm{PL}_{2}$, respectively. Furthermore, this higher milk production may have been the result of a greater efficiency in the use of body reserves for milk production, due to a higher protein content in the ration (Cowan et al, 1981).

The higher fat, protein and total dry matter productions in the milk from ewes on $\mathrm{PL}_{1}$ as compared to those on $\mathrm{PL}_{2}(P<0.05)$ are the result of the higher milk production of the former as compared to the latter $(P<0.05)$, since there were no significant differences in the concentrations of these milk components. When the total fat and protein amounts secreted in the milk were related to the initial $\mathrm{BCs}$, the correlation coefficients obtained were 0.78 and 0.63 , respectively $(P<0.001)$. This fact suggests again that the ewes with the best body con- dition at lambing have a greater ability to mobilize their body reserves for milk production.

The mean daily gain of lamb litters was directly related to milk production ( $r=0.64$; $P<0.001)$, consumption of total dry matter ( $r=0.67 ; P<0.001)$ and energy from the milk $(r=0.65 ; P<0.001)$, estimated from Alvarez et al (1985). The results obtained indicate that the lambs had to ingest about $5.2 \mathrm{~kg}$ milk (or $1.0 \mathrm{~kg}$ total dry matter) to gain $1 \mathrm{~kg} \mathrm{LW}$. This value is of the same magnitude as those proposed by INRA (1988) and MLC (1981).

The lambs born from the ewes on the lower protein level consumed greater amounts of concentrates in the 18 days preceding weaning $(P=0.07)$. During this period, however, the growth of the litters on the two protein levels was very similar (232 and 228 $\mathrm{g} / \mathrm{d}$, respectively, for levels $\mathrm{PL}_{1}$ and $P L_{2}$ ), 
which suggests that the ewes on $\mathrm{PL}_{2}$ continued to produce less milk during that period.

The high average NEFA concentrations ( $1.04 \mathrm{meq} / \mathrm{l})$, due to the strong energy restriction (Chilliard et al, 1987), were of the same magnitude as those found by Robinson et al (1979) in ewes with 2 lambs submitted to a level of energy restriction similar to that of this trial. The highest NEFA concentrations corresponded to the highest milk productions $(r=0.44 ; P<0.01)$. On the other hand, the average concentration of NEFA was significatively correlated with the BCs losses $(r=0.81 ; P<0.001)$, which confirms NEFA concentration as a good indicator of fat mobilization.

The increase in plasma urea concentration as a result of the increase in the $\mathrm{CP}$ level of the ration $(P<0.05)$ has been observed by many authors. González et al (1984) found an increase from 23.8 to 49.1 $\mathrm{mg} / \mathrm{dl}(P<0.001)$ when the protein concentration in the ration increased from 12.8 to $18.6 \%$. The relatively high urea concentrations observed $(49.1 \mathrm{mg} / \mathrm{dl})$ suggest the existence of high $\mathrm{NH}_{3}$ concentrations in the rumen or the formation of urea as a consequence of the metabolism of the body proteins that presumably have been mobilized for milk production.

\section{ACKNOWLEDGMENTS}

The authors acknowledge the "Instituto Nacional de Investigaciones Agrarias (INIA, Spain)" for the grant awarded to carry out this work (Project 8526).

\section{REFERENCES}

Alvarez PJ, Ovejero FJ, Guada JA (1985) Estimación del contenido energético de la leche de oveja a partir de los datos de su composición. An INIA Ser Ganadera 22, 39-50

Chilliard Y, Sauvant D, Morand-Fher P, Delouis C (1987) Relations entre le bilan énergétique et l'activité métabolique du tissu adipeux de la chèvre au cours de la première moitié de la lactation. Reprod Nutr Dev 27, 307-308
Cowan RT, Robinson JJ, McHattie I, Pennie K (1981) Effect of protein concentration in the diet on milk yield, change in body composition and the efficiency of utilization of body tissue for milk production in ewes. Anim Prod 33, 111-120

Cowan RT, Robinson JJ, McDonald I (1982) A note on the effects of body fatness and level of food intake on the rate of fat loss in lactating ewes. Anim Prod 34, 355-357

Doney JM, Peart JN, Smith WF, Louda F (1979) A consideration of the techniques for estimation of milk yield by suckled sheep and a comparison of estimates obtained by 2 methods in relation to the effect of breed, level of production and stage of lactation. $\checkmark$ Agric Sci Camb 92, 123-132

Gibb MJ, Treacher TT (1980) The effect of ewe body condition at lambing on the performance of ewes and their lambs at pasture. J Agric Sci Camb 95, 631-640

González JS, Robinson JJ, McHattie I, Fraser C (1982) The effect in ewes of source and level of dietary protein on milk yield, and the relationship between the intestinal supply of non-ammonia nitrogen and the production of milk protein. Anim Prod 34, 31-40

González JS, Robinson JJ, Machlattie I (1984) The effect of level of feeding on the response of lactating ewes to dietary supplements of fish meal. Anim Prod 40, 39-45

Hadjipanayiotou M (1992) Effect of protein source and formaldehyde treatment on lactation performance of Chios ewes and Damascus goat. Small Rum Res 8, 185-197

INRA (1988) Alimentation des Bovins, Ovins et Caprins. INRA Publ, Versailles, France

MLC (1981) Feeding the Ewe. Meat and Livestock Commission, Bletchley, UK

Ngongoni NT, Robinson JJ, Aitken RP, Fraser C (1989) Efficiency of utilization during pregnancy and lactation in the ewe of the protein reaching the abomasum and truly digested in the small intestine. Anim Prod 49, 249-265

Penning PD, Orr RJ, Treacher TT (1988) Responses of lactating ewes, offered tresh herbage indoors and when grazing, to supplements containing differing protein concentrations. Anim Prod 46, 403-415

Robinson JJ (1988) Energy and protein requirements of the ewe. In: Recent developments in ruminant nutrition-2 (W Haresign, DJA Cole, eds), Butterworths, London, 365-382

Robinson JJ, Fraser C, Gill JC, McHattie I (1974) The effect of dietary crude protein concentration and time of weaning on milk production and body-weight change in the ewe. Anim Prod 19, 331-339

Robinson JJ, McHattie I, Calderón-Cortés JF, Thompson $J L$ (1979) Further studies on the response of lactating ewes to dietary protein. Anim Prod 29, 257-269

Russel AJF, Doney JM, Gunn RG (1969) Subjective assessment of body fat in live sheep. J Agric Sci Camb 72, 451-454

SAS (1987) SAS/stat user's guide. Version 6.04. SAS Institute Inc, Cary, NC, USA 